\title{
REPORT OF THE SUB-COMMITTEE ON EDUCATION
}

D

URING 1936 Dr. P. M. Barr of the University of California reviewed forestry and forest educational conditions in British Columbia at the request of the University of British Columbia and submitted for the consideration of the University authorities a proposed new curriculum for the school of forest engineering at the University of B.C. This new cur, riculum outlines opportunities for four programs of study covering four years under each program and with a fifth year following any one of these programs devoted to professional study in forestry. I will quote from his report to clarify this introduction:

"1. The present curriculum in Forest Engineering should be abandoned as an exclusive approach to professional forestry employment and instead, opportunities for technical education should be provided by the following four programs of study, although without prejudice to other curricula which may also be found appropriate.

(a) A four-year Arts course with major or honours in Botany, lead. ing to the B.A. degree. This would provide sound fundamental training for later employment of graduate study in forest production or silvicultural research.

(b) A four-year Arts course with major or honours in Government (B.A.). Such a program would be of peculiar benefit to men entering the government forest services in an administrative capacity.

(c). The present course leading to the degree of Bachelor of Commerce, which gives highly satisfactory preparation for participation in the business life of the Province.

(d). The existing curriculum in Civil Engineering, or the first four years thereof. Such a course of study lays an excellent foundation for logging engineering and employment in connection with engineering aspects of the manufacturing industries.

2. In each of the above preparatory curricula the following courses should be included, being compulsory as regards the five-year forestry course but regarded as electives in each of the undergraduate curricula.

SECOND YEAR

(a). General forestry (New course, 3 units).

(b). Field work in elementary surveying. (Civ. Eng. 2;2 units; taken at the close of spring examinations).

THIRD YEAR

(c). Dendrology. It is suggested that this should be a broad, scientific survey of the morphology, physiology, and taxonomy of trees, with emphasis. 
on species of economic importance, (3 units). It should not of necessity require prerequisite botanical courses and should offer in somewhat enlarged degree the work now covered in Botany 5 (b) (2 units). It could be given by either the Department of Botany or the member of the forestry staff specializing in the field of forest production, depending on the qualifications of the latter.

(d). Lecture course in elementary surveying. (Civ. Eng. 6;2 units). FOURTH YEAR

(e) Forest economics. ( 3 units). This is the new course proposed on page 11.

(f). Forestry field work. (2 units). A new group of field exercises in mensurational and silvicultural methods, to be given by the Department of Forestry at the close of the spring examinations.

The writer believes that the three general courses in forestry listed above, (a), (c) and (e), should be open to non-forestry students in Arts, Applied Science and Agriculture who might wish to include them as electives in their own programs of undergraduate study. Such a plan would have the desirable effect of causing forestry to be included in the general educational facilities offered by the University, rather than being restricted to a professional course, as at present.

3. The main program of technical courses in forestry, apart from those indicated above, should be organized as a fifth year of thorough professional study, admission to which would be based on completion of any one of the four preparatory curricula which have been described in section (1). The following arrangement of courses is suggested for this final year, as a basis for consideration.

\begin{tabular}{|c|c|c|c|}
\hline 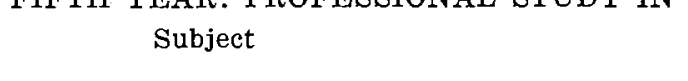 & \\
\hline \multicolumn{4}{|l|}{ Fall Term } \\
\hline Wood Technology & 4 & 4 & 3 \\
\hline Forest Mensuration & 3 & 2 & 2 \\
\hline Log Scaling ....... & 1 & 4 & 1 \\
\hline Forest Ecology $\ldots \ldots$ & 2 & - & 1 \\
\hline Forest entomology & 1 & 2 & 1 \\
\hline Logging Engineering .. & 3 & 2 & 2 \\
\hline Thesis $\ldots . . . . .$. & 1 & - & 1 \\
\hline \multirow{3}{*}{ Seminar } & 1 & - & 1 \\
\hline & - & - & \\
\hline & 16 & 14 & \\
\hline
\end{tabular}




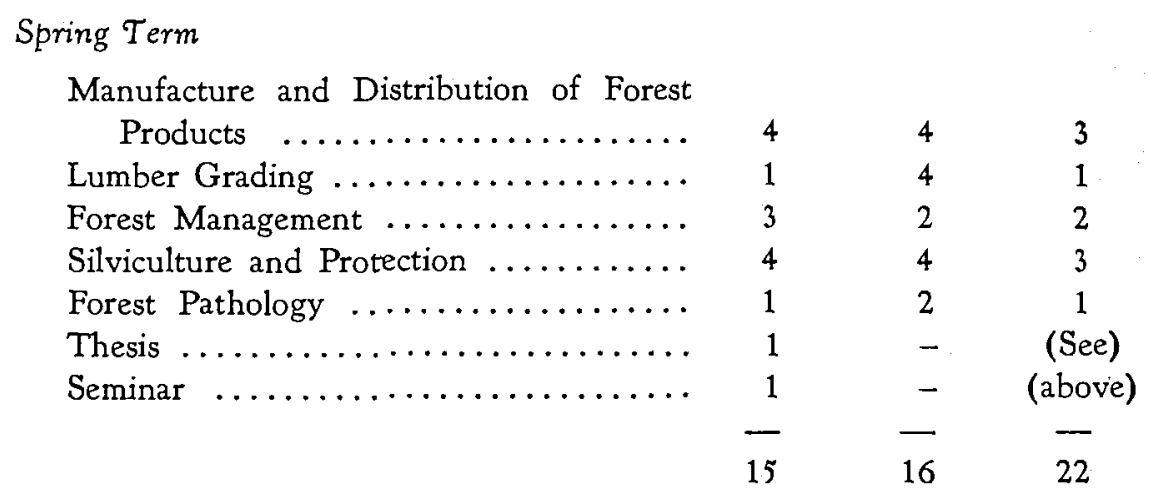

Notz: Men who prepare in civil engineering for this year should take Civ. Eng. 51, Design of Timber Structures, in addition to the above program. Consideration should also be given to the possibility of including the existing courses in engineering economics (Civ. Eng. 18) and law (Civ. Eng. 19) in the fifth year program, as either elective or required subjects.

The writer of this report would favor the granting of the degree of B.A.Sc. (Forestry) to all students completing the work of the proposed fifth year of forestry courses as outlined above. It would be advisable, however, to establish a definite policy in regard to the status of the forestry courses proposed as preparatory instruction in the second, third, and fourth years. It is suggested that these courses should be defined as prerequisite to the work of the final year."

This suggested preliminary training before the year of professional work in forestry emphasizes the need of broader educational training, and will bring to the professional year of forestry, students of more mature years. To assist in introducing this work at the University of British Columbia, Professor A. B. Recknagel of Cornell University has been temporarily appointed during his Sabbatical year from Cornell. 